\title{
PENDAMPINGAN MANAJEMEN USAHA GUNA MEWUJUDKAN PEMULIHAN EKONOMI KELOMPOK WANITA TANI DI MASA PANDEMI
}

\author{
Cahyana Nursidiq ${ }^{1}$, Itsna Iftayani ${ }^{2}$ \\ ${ }^{1}$ Universitas Muhammadiyah Purworejo \\ ${ }^{2}$ Universitas Muhammadiyah Purworejo \\ cahyana@umpwr.ac..id, itsnaiftayani@umpwr.ac.id
}

\begin{abstract}
Abstrak
Program pendampingan kepada masyarakat bertujuan untuk untuk membantu mitra dalam memulihkan kondisi perekonomian anggota melalui kegiatan pendampingan usaha. Mitra dalam program ini adalah KWT Srikandi yang mengelola usaha keripik singkong. Permasalahan yang dihadapi mitra pada usaha ini adalah kurangnya pengetahuan mengenai pengelolaan usaha, belum memiliki motivasi yang tinggi untuk mengembangkan usaha sehingga ketika pandemi, usaha keripik singkong yang sedang dirintis dibiarkan berhenti, pemasaran yang masih terbatas dengan konsinyasi di area tempat produksi, belum memiliki keterampilan pemasaran online, belum memiliki merk dagang dan belum memiliki manajemen usaha yang baik. Mitra juga memiliki keterbatasan dalam peralatan sehingga proses pembuatan masih dilakukan secara manual. Berdasarkan permasalahan tersebut, beberapa metode yang telah dilakukan adalah (1) pelatihan pengelolaan usaha baik dari manajemen organisasi maupun pentingnya brand (merk) dalam usaha, (2) pembuatan media pemasaran online yaitu Instagram dan shopee, (3) rekayasa alat pemotong keripik yang aman dan ergonomis dan juga kemasan yang menarik. Hasil yang diperoleh dari program pendampingan ini adalah (1) adanya manajemen organisasi yaitu struktur organisasi dan deskripsi kerja yang jelas, (2) adanya merk dagang yang cukup menarik, (3) penjualan meluas hingga berbagai provinsi di Indonesia dan (4) kapasitas produksi meningkat cukup signifikan. Dampak positif yang didapatkan oleh masyarakat adalah pulihnya perekonomian anggota KWT Srikandi.
\end{abstract}

Kata Kunci : Pendampingan, Kelompok wanita tani, Purworejo, pemulihan ekonomi.

\section{PENDAHULUAN}

1. Latar Belakang

Pandemi covid memberikan dampak dalam berbagai sektor, diantaranya adalah sektor pendidikan, perkantoran dan juga sektor usaha. Banyak perusahaan besar terdampak pandemi yang kemudian terpaksa harus mengambil keputusan untuk melakukan pemutusan hubungan kerja (Sulaeman, 2021). Selain munculnya banyak pemutusan hubungan kerja, Pandemi juga sangat berdampak pada pelaku usaha kecil dalam mempertahankan usahanya (Sudjatmiko, n.d.).

Dampak pandemi ini juga dialami oleh salah satu usaha pemula keripik singkong yang ada di Purworejo yang menjadi mitra dalam Program Kemitraan Masyarakat (PKM). Dampak pandemi dirasakan oleh KWT Srikandi karena beberapa permasalahan mendasar, berdasarkan hasil 
wawancara yang dilakukan kepada anggota KWT, ada beberapa permasalahan yang dihadapi, salah satunya adalah kurangnya pengetahuan mengenai pengelolaan usaha. Munculnya usaha keripik singkong dilatarbelakangi oleh banyaknya bahan baku singkong yang ada di masyarakat namun biasa dijual dengan harga rendah sehingga untuk menambah nilai jualnya, singkong diolah menjadi keripik singkong. Hal lain yang mendasari dikembangkannya usaha ini adalah banyaknya anggota KWT Srikandi yang belum memiliki kegiatan rutin sehingga waktu luang mereka dapat dimanfaatkan dengan kegiatan pengembangan pertanian dan pengolahannya,

Usaha keripik singkong ini dikembangkan dengan bahan dan alat seadanya. Sejauh ini peralatan yang digunakan adalah peralatan manual seperti memotong dengan pisau biasa, memasak dengan tungku kayu dan juga mengemas dengan plastik kiloan. Keterbatasan peralatan tersebut berdampak kepada hasil yang didapatkan, selain itu juga proses pengerjaan membutuhkan waktu yang lama dan mempengaruhi jumlah produksi keripik singkong tersebut. Berikut gambaran proses produksi sebelum didampingi.

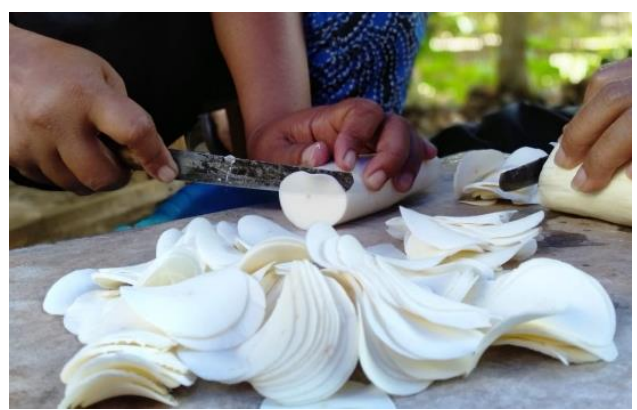

Gambar 1. Proses Pemotongan Singkong dengan pisau

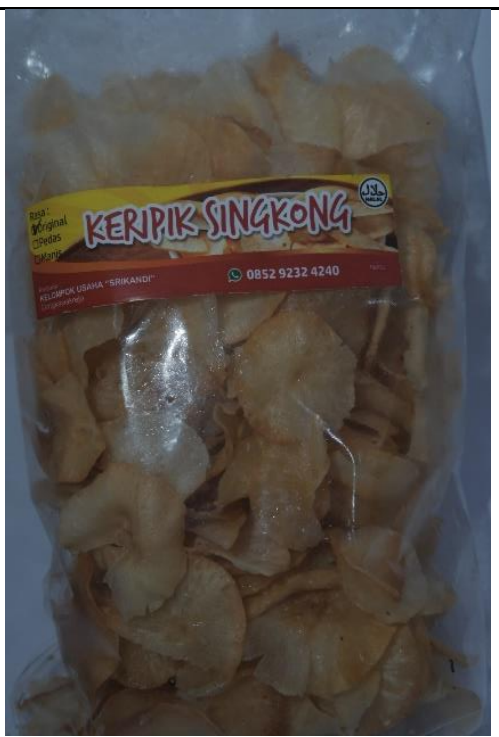

Gambar 2. Kemasan Keripik Singkong

Permasalahan yang lain adalah motivasi usaha beberapa anggota yang rendah. Beberapa mitra masih belum memiliki gambaran mengenai bagaimana pengelolaan usaha, seberapa besar profit akan didapatkan dan juga gambaran pemasaran yang memadai. Orientasi mereka masih sebatas mengisi waktu luang jadi mereka hanya akan memproduksi keripik singkong ketika ada kegiatan atau acara bersama. Anggota KWT juga pesimis dengan usaha tersebut.

Motivasi semakin rendah karena adanya pandemi, beberapa warung yang selama ini dititipi sudah tidak menerima titipan karena berkurangnya pembeli sehingga produksi hanya dilakukan jika ada permintaan saja.

Kendala terbesar dalam pengelolaan usaha ini adalah keterampilan pemasaran yang belum baik. Mitra hanya bisa menjual dengan sistem titip jual di warung-warung kecil saja seperti di pemancingan, warung sembako dan warung makanan di sekitar tempat tinggal. Mitra belum memiliki keinginan untuk memperluas penjualan karena masih belum percaya diri dengan kualitas produk yang dihasilkan. Selain itu juga kemasan belum menarik sehingga belum berani menjual secara luas. Masalah keawetan produk juga menjadi kendala yang cukup besar bagi mitra.

Berdasarkan beberapa permasalahan diatas 
maka prioritas penyelesaian masalah yang dilakukan dalam PKM ini adalah sebagai berikut, (1) Memperbaiki pengelolaan usaha (struktur organisasi, manajemen keuangan, motivasi wirausaha dan mengembangkan merk dagang), (2) memberikan pelatihan pemasaran online untuk meningkatkan penjualan dan memperluas pemasaran, (3) mengidentifikasi kembali peralatan produksi yang dibutuhkan serta memberikan bantuan alat produksi dan (4) meningkatkan motivasi wirausaha dengan pendampingan yang intensif.

2. Tujuan Program

Program kemitraan masyarakat ini secara umum bertujuan untuk membantu mitra dalam memulihkan kondisi perekonomian anggota mitra melalui pendampingan kegiatan. Sedangkan secara spesifik kegiatan ini bertujuan untuk 1) membantu mitra dalam memperbaiki pengelolaan usaha, 2) meningkatkan keterampilan mitra melalui berbagai pelatihan, 3) membantu meningkatkan produktivitas usaha keripik singkong dan 4) meningkatkan motivasi wirausaha anggota mitra dalam mengembangkan usahanya

3. Urgensi Program

Program kemitraan ini sangat penting dilakukan yaitu sebagai bentuk pendampingan kepada mitra mengingat mitra memiliki masalah cukup mendasar yaitu terkait motivasi, pengetahuan, peralatan dan pengelolaan usaha yang kemudian sempat terhenti karena pandemi. Sehingga perlu adanya pendampingan intensif agar usaha tersebut dapat beroperasi kembali.

\section{METODE}

Metode yang diterapkan dalam program kemitraan masyarakat ini adalah metode pemberdayaan Developmental Approach. Pendekatan ini bertujuan untuk mengembangkan proyek pembangunan untuk meningkatkan kemampuan, kemandirian dan keswadayaan masyarakat. Pendekatan ini membutuhkan motivasi, penguatan dan pengetahuan untuk dapat memecahkan masalah yang mereka hadapi. Model pemberdayaan ini dikembangkan dan disesuaikan dengan kondisi Kelompok Wanita Srikandi yang sedang mengembangkan usaha keripik. Model pemberdayaan ini memuat beberapa prinsip yaitu authority, confidence and competence, trust, opportunities, responsibilities dan support (Maani, 2011). Selain dengan memberikan beberapa prinsip tersebut, program ini juga mengenalkan beberapa kebijakan-kebijakan terkait UMKM sebagai bentuk memberikan pengetahuan dasar dalam pengelolaan usaha yang legal (Patel \& Hochfeld, 2013).

Tahapan-tahapan dalam implementasi metode pemberdayaan tersebut adalah sebagai berikut.

1. Melaksanakan Focus Group Discussion dengan anggota mitra dan beberapa stakeholder untuk reorientasi visi KWT dan menentukan langkah awal untuk pengembangan usaha.

2. Memberikan motivasi wirausaha untuk meningkatkan rasa percaya diri anggota mitra sekaligus memberikan gambaran bagaimana pengembangan usaha yang mudah dan sederhana.

3. Membentuk struktur organisasi baru dan pembagian usaha yang jelas. Hal ini bertujuan untuk membagi peran secara adil sehingga masing-masing anggota KWT fokus pada pekerjaan masing-masing.

4. Membangun branding dengan menetapkan merk, logo dan tagline.

5. Memberikan beberapa pelatihan berkaitan dengan pengelolaan usaha mulai dari branding, marketing, accounting, dan packaging

6. Mendesain kemasan yang menarik dan ekonomis

7. Penerapan teknologi yaitu alat produksi yang dibutuhkan mulai dari alat untuk memotong, kompor, gas dan beberapa peralatan lainnya

8. Pembuatan media pemasaran online dan mempromosikannya

9. Monitoring dan evaluasi

10. Tindaklanjut

\section{HASIL DAN PEMBAHASAN}

Program kemitraan masyarakat ini bertujuan untuk membantu mitra dalam memulihkan ekonomi anggota mitra. Mitra dalam kegiatan ini adalah anggota kelompok Wanita tani (KWT) Srikandi, yang terletak di desa Cengkawakrejo, Kecamatan Banyuurip, Kabupaten Purworejo. Program kemitraan masyarakat ini dilaksanakan semenjak 
bulan April hingga bulan Desember 2021 secara bertahap dalam 3 tahapan yaitu tahapan pertama adalah identifikasi dan perencanaan kegiatan, tahap kedua pelaksanaan kegiatan dan tahap terakhir adalah evaluasi dan tindak lanjut program. Pada tahap kedua ini proses pelaksanaan sudah selesai dilaksanakan.

Program kemitraan masyarakat ini memuat beberapa pendampingan yaitu terkait motivasi, branding, marketing dan manajemen usaha atau organisasi. Hasil yang didapatkan dari program kemitraan masyarakat ini adalah sebagai berikut.

\section{Manajemen Organisasi}

Manajemen merupakan hal yang penting dalam proses usaha. Manajemen mencakup proses perencanaan, pendistribusian, pelaksanaan dan evaluasi (Rohim \& Kurniawan, 2016, 2017). KWT Srikandi belum memiliki manajemen organisasi yang baik, hal ini dapat dilihat dari belum adanya struktur organisasi yang jelas, pembagian kerja yang terstruktur dan juga pencatatan keuangan yang rapih.

Kegiatan pendampingan manajemen usaha dimulai dengan Focus Group Discussion (FGD) dengan anggota mitra dan ketua BUMDES Cengkawakrejo. Langkah memperbaiki manajemen dimulai dengan menganalisis struktur organisasi yang tepat untuk KWT Srikandi. Setelah menganalisis kebutuhannya, maka disusun struktur organisasi dan dilakukan distribusi pekerjaan sesuai dengan kebutuhan mitra. Mitra, dengan dibantu oleh tim pengabdian masyarakat mengisi nama-nama yang akan diminta untuk mengelola bidang tertentu. Setelah ditentukan distribusi kerja, maka pembagian kerja pada masing-masing bidang disampaikan kepada anggota KWT sehingga masing-masing anggota KWT memahami tugasnya.

Pengelolaan usaha juga dilakukan dengan menghitung Harga Pokok Penjualan (HPP) untuk merencanakan harga produksi yang pasti dan standar. Setelah adanya pengelolaan ini, proses produksi, pencatatan keuangan dan pemasaran menjadi lebih tertata. Meskipun masih ada kendala dalam pengelolaan pemasaran online namun sudah ada keinginan belajar yang tinggi dari tim pemasaran.

\section{Merk Dagang/ Brand Produk}

Merk dagang menjadi salah satu hal penting dalam meningkatkan penjualan dan memperluas pemasaran. Merk dapat meningkatkan kepercayaan dan loyalitas konsumen terhadap produk (Kim \& Chao, 2019; Ngatno, 2017).

Sebelum adanya proses pendampingan, mitra belum menggunakan merk dalam memasarkan produknya, mitra hanya menempel sticker yang berisi jenis makanan dan nomor $\mathrm{Hp}$ yang bisa dihubungi. Belum adanya merk ini tentu sangat berdampak pada perluasan pemasaran produk yang akan dilakukan.

Berdasarkan diskusi dengan anggota KWT Srikandi, merk yang disepakati adalah "Aku tela". Hal ini berdasarkan pertimbangan nama ini sederhana, mudah diingat dan menggambarkan produk yang dijual. Berdasarkan penelitian, merk yang mudah dikenal akan memberikan dampak terhadap proses penjualan produk (Rosandi \& Sudarwanto, 2014).

Bersamaan dengan merk juga dibuat logo dan tagline untuk memberikan ciri khas agar produk lebih mudah dikenal oleh masyarakat. Berdasarkan riset terdahulu, tagline dan brand ambassador mempunyai pengaruh yang signifikan terhadap brand awareness produk. Brand awareness dapat meningkatkan minat pembelian terhadap produk (Saputri et al., 2020). Selain tagline, logo juga memiliki hubungan dengan brand awareness(Safrian, 2015).

\section{Peningkatan Produksi}

Permasalahan yang menghambat proses produksi adalah keterbatasan alat produksi terutama alat pemotong singkong dan alat untuk menggoreng singkong. Setelah diberikan peralatan produksi berupa alat pemotong singkong otomatis, kompor dan gas maka dapat dilihat adanya peningkatan produksi produk. Penelitian sebelumnya menyebutkan bahwa peralatan produksi modern dapat meningkatkan kapasitas produksi (Sudiarso \& Kusumawardani, 2018).

Peningkatan produksi keripik singkong dapat dilihat pada grafik berikut.

Ekonomi, Sosial, dan Budaya 


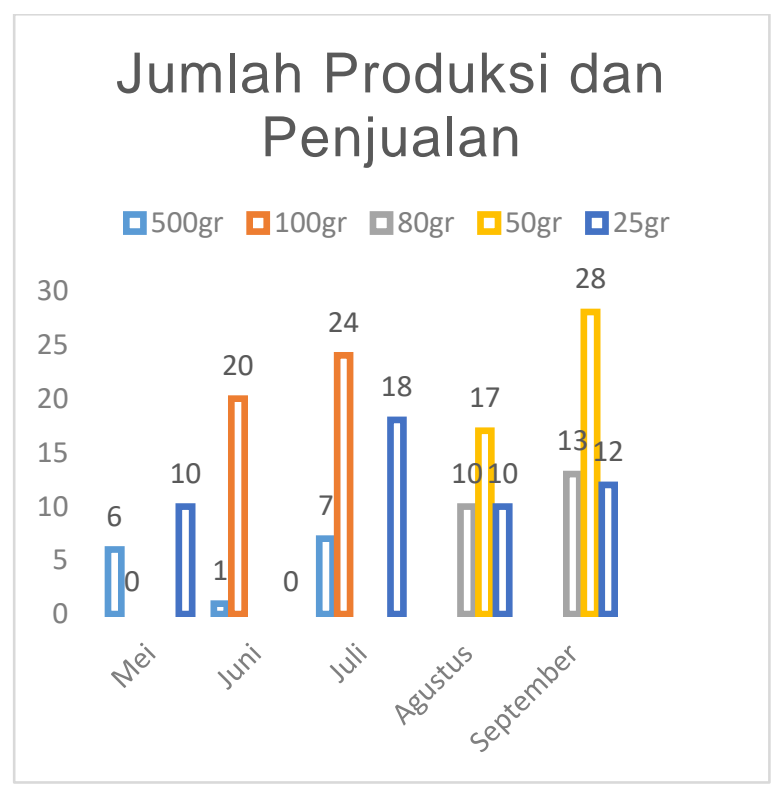

Gambar 3. Grafik Produksi Mei-September

\section{Peningkatan Pemasaran}

Berdasarkan diskusi dengan tim pengabdian dan pengurus KWT maka disepakati bahwa media promosi online yang akan digunakan adalah media sosial dan market place. Pada bidang pemasaran, dilakukan dua program yaitu pembuatan akun, pengelolaan dan juga pelatihan penggunakan akun penjualan yang akan digunakan. Pelatihan diberikan secara khusus kepada bidang pemasaran.

Untuk memudahkan fokus pengelolaan, maka hanya akan digunakan masing-masing satu jenis media yaitu satu akun media sosial dan satu akun market place. Media sosial yang digunakan adalah Instagram, pertimbangan menggunakan Instagram adalah karena pada beberapa tahun terakhir Instagram menjadi media sosial yang paling disukai oleh masyarakat terutama remaja dan dewasa awal. Selain itu berdasarkan riset terdahulu, Instagram juga dianggap sebagai media yang efektif untuk meningkatkan penjualan (Khairani et al., 2018; Kurnianto, 2020). Pada Instagram ada aspek hiburan, interaksi, popular, iklan dan mengutamakan pelanggan (Aji et al., 2020). Berikut akun Instagram yang dikembangkan untuk promosi dan penjualan produk.

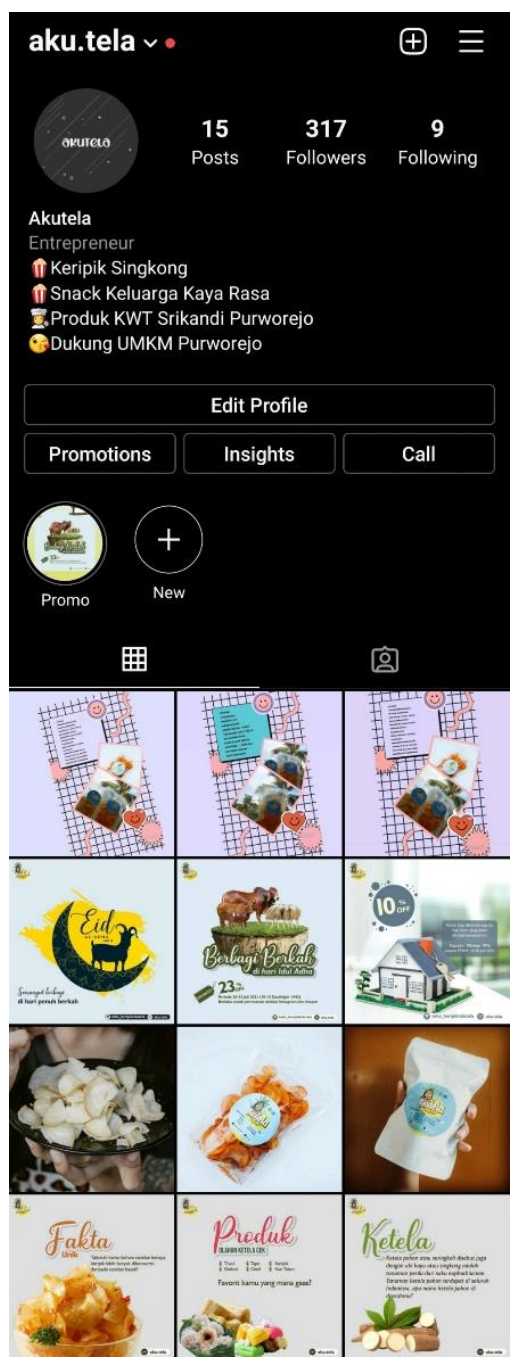

Gambar 4. Akun Instagram Aku.tela

Selain Instagram, tim pengabdian masyarakat memilih menggunakan akun shopee. Shopee digunakan karena fitur yang cukup sederhana namun termasuk salah satu market place yang banyak digunakan, bahkan menjadi akun terpopuler karena sangat gencarnya iklan di televisi, youtube dan media yang lain. Berdasarkan penelitian sebelumnya, shopee juga dapat meningkatkan penjualan produk (Suswanto \& Setiawati, 2020; Widyastuti \& Nugroho, 2018). Penggunaan shopee ini menjadi salah satu bentuk komunikasi penjualan antara penjual dengan konsumen. Shopee memiliki fitur live chat dan live video untuk membangun komunikasi dengan konsumen. Produk yang 
ditawarkan juga cukup bervariasi mulai dari gadget, fashion, kosmetik, elektronik, otomotif dan berbagai produk lain (Suswanto \& Setiawati, 2020).

Berdasarkan data penjualan, setelah dibuatkan akun shopee, pemasaran produk dapat meluas ke berbagai kota di Jawa. Hal ini menunjukkan bahwa shopee menjadi alternatif penjualan yang tepat bagi aku.tela. Penjualan dapat dilihat dari gambar berikut.

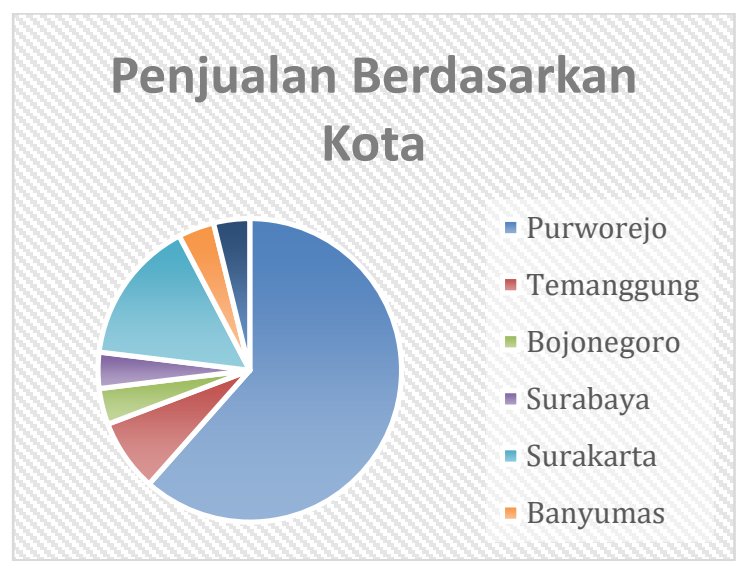

Gambar 4. Penjualan Berdasarkan Kota

Beberapa program yang dilaksanakan oleh tim Program Kemitraan Masyarakat secara umum memperoleh hasil yang baik. Dampak yang diperoleh mitra adalah 1) adanya pengetahuan yang cukup memadai terkait pengelolaan usaha, 2) peralatan yang memadai dan juga pelatihan pemasaran online dapat meningkatkan produksi dan memperluas penjualan. Hal ini tentu berpengaruh terhadap pemulihan ekonomi bagi anggota KWT. Berhasilnya program pendampingan ini sejalan dengan berjalannya usaha yang dikembangkan oleh KWT Srikandi.

Program kemitraan masyarakat ini sudah dilaksanakan secara optimal namun berdasarkan Evaluasi awal, masih ada beberapa program yang perlu adanya tindak lanjut seperti pelatihan penggunaan media sosial lanjutan yaitu terkait konten promosi dan fotografi lanjutan untuk produk. KESIMPULAN

Program kemitraan masyarakat dilaksanakan melalui beberapa kegiatan yaitu FGD dan pelatihan motivasi usaha untuk memperbaiki manajemen usaha yang belum tertata, memberikan alat-alat produksi yang memadai dan memberikan pelatihan pemasaran online. Berdasarkan beberapa kegiatan tersebut, dapat dilihat melalui peningkatan produksi dan perluasan penjualan yang diharapkan dapat membantu memulihkan perekonomian anggota KWT Srikandi.

Hambatan yang dialami dalam program ini adalah rendahnya motivasi anggota KWT Srikandi untuk belajar hal baru terutama yang berkaitan dengan teknologi, sehingga untuk meyakinkan bahwa mereka bisa menggunakan model pemasaran secara online membutuhkan waktu yang cukup lama. Menjadi tantangan cukup besar untuk mengubah mindset wirausaha sehingga terus memiliki motivasi untuk belajar. Program kemitraan masyarakat ini juga memiliki keterbatasan yaitu masih tingginya angka covid 19 di Kabupaten Purworejo sehingga beberapa pelatihan yang idealnya dilakukan secara langsung atau luring terpaksa diberikan melalui whatsapp, modul dan video.

Adanya hambatan dan keterbatasan dari program kemitraan masyarakat ini dapat menjadi evaluasi bagi program kemitraan masyarakat berikutnya. Rekomendasi bagi tim program pengabdian masyarakat berikutnya adalah mempersiapkan program dengan lebih matang, termasuk mengenal latar belakang mitra secara mendalam agar dapat memilih program yang sesuai dengan latar belakang mitra.

\section{UCAPAN TERIMAKASIH}

Ucapan terimakasih disampaikan kepada Kemendikbud Ristek yang telah memberikan dana dalam Program Kemitraan Masyarakat dan Pemerintah Desa Cengkawakrejo yang telah memberikan izin dan kesempatan kepada kami untuk melaksanakan Program di Desa Cengkawakrejo.

\section{REFERENSI}

Aji, P. M., Nadhila, V., \& Sanny, L. (2020). Effect of social media marketing on instagram towards purchase intention: Evidence from Indonesia's ready-to-drink tea industry. International Journal of Data and Network Science, $\quad 4(2), \quad 91-104$. 
https://doi.org/10.5267/j.ijdns.2020.3.002

Khairani, Z., Soviyant, E., \& Aznuriyandi, A. (2018). Efektivitas Promosi Melalui Instagram Pada Umkm Sektor Makanan Dan Minuman Di Kota Pekanbaru. Jurnal Benefita, 3(2), 239. https://doi.org/10.22216/jbe.v3i2.2738

Kim, R. B., \& Chao, Y. (2019). Effects of brand experience, brand image and brand trust on brand building process: The case of chinese millennial generation consumers. Journal of International Studies, 12(3), 9-21. https://doi.org/10.14254/2071-8330.2019/12$3 / 1$

Kurnianto, Y. T. R. I. (2020). PEMANFAATAN MEDIA SOSIAL INSTAGRAM SEBAGAI MEDIA PROMOSI PEMASARAN MINUMAN DI BANJARBARU ( Studi Pada Akun Instagram@tempatbiasa.kopi ).

Maani, K. D. (2011). Teori ACTORS dalam Pemberdayaan Masyarakat. Jurnal Demokrasi.

Ngatno, N. (2017). Effect of Brand Communication and Experience on Loyalty: Mediating Effect of Brand Satisfaction and Trust. (Case Study of Customers of Inul Vista Karaoke, Semarang, Central Java, Indonesia). Archives of Business Research, 5(4). https://doi.org/10.14738/abr.54.2828

Patel, L., \& Hochfeld, T. (2013). Developmental social work in South Africa: Translating policy into practice. International Social Work, 56(5), 690-704. https://doi.org/10.1177/0020872812444481

Rohim, A., \& Kurniawan, I. (2016). Manajemen Usaha Dan Produksi Pada Usaha Mikro, Kecil Dan Menengah (UMKM) Di Desa Carang Wulung Wonosalam. Jurnal Enterpreuner dan Enterpreneurship, 5(1), 19-25. https://doi.org/10.26533/comvice.v1i1.116

Rohim, A., \& Kurniawan, I. (2017). Manajemen Usaha Dan Produksi Pada Usaha Mikro, Kecil Dan Menengah (UMKM) Di Desa Carang Wulung Wonosalam. Comvice: Journal of community service, 1(1), 23-28. https://doi.org/10.26533/comvice.v1i1.116
Rosandi, S., \& Sudarwanto, T. (2014). Pengaruh Citra Merek dan Desain Kemasan Terhadap Minat Beli Konsumen pada Produk Susu Ultra. Jurnal Pendidikan Tata Niaga, 2(2), 116.

Safrian, A. A. (2015). Pengaruh logo terhadap kesadaran merek. UIN Sunan Kalijaga.

Saputri, D., Mulyatini, N., \& Basari, A. (2020). Pengaruh Tagline dan Brand Ambassador terhadap Brand Awareness (Studi pada Produk Motor Yamaha di PT Bahana Cahaya Sejati Ciamis). Bussiness Management and Entrepreneurship Journal, 2(417), 80-92.

Sudiarso, A., \& Kusumawardani, R. (2018). Implementation of Batik Machine to Improve Hand - Drawn Batik Production Time. International Conference on Community Engagement and Education for Sustainable Development (ICCEESD), 24, 150-157.

Sudjatmiko, T. (n.d.). 24 Ribu UMKM di Purworejo Terdampak Covid-19 - KRJOGJA. Diambil 28 Juli 2020, dari https://www.krjogja.com/beritalokal/jateng/kedu/24-ribu-umkm-dipurworejo-terdampak-covid-19/

Sulaeman. (2021). Menaker: 17,8 Persen Perusahaan PHK Karyawan Selama Pandemi Covid-19 | merdeka.com. Merdeka.com. https://www.merdeka.com/uang/menaker-178perusahaan-phk-karyawan-selama-pandemicovid-19.html

Suswanto, P., \& Setiawati, S. D. (2020). Strategi Komunikasi Pemasaran Shopee Dalam Membangun Positioning Di Tengah Pandemi Covid-19 Di Indonesia. Linimasa: Jurnal Ilmu Komunikasi, 3(2), 16-29. http://52.221.78.156/index.php/linimasa/articl e/view/2754

Widyastuti, D. A., \& Nugroho, M. R. (2018). EFEKTIVITAS TAGLINE \# DijaminOri TERHADAP BRAND AWARENESS ECOMMERCE JD . ID. Journal of Entrepreneurship, Management, and Industry, 1(4), 211-225.

Ekonomi, Sosial, dan Budaya 1240 